\title{
Correction to: Root tensile strength and root distribution of typical Mediterranean plant species and their contribution to soil shear strength
}

\author{
S. De Baets • J. Poesen • B. Reubens • K. Wemans • \\ J. De Baerdemaeker • B. Muys
}

Published online: 2 April 2018

(C) Springer International Publishing AG, part of Springer Nature 2018

Correction to: Plant Soil (2008) 305, 207-226

https://doi.org/10.1007/s11104-008-9553-0

The original version of this article unfortunately contained a mistake. Fig. 4a, c were duplicated. This Figure has now been corrected.

The online version of the original article can be found at https://doi.org/10.1007/s11104-008-9553-0

S. De Baets $\cdot$ J. Poesen $(\varangle) \cdot K$. Wemans

Physical and Regional Geography Research Group, K.U. Leuven, Celestijnenlaan 200E, 3001 Leuven, Belgium

e-mail: jean.poesen@geo.kuleuven.be

B. Reubens · B. Muys

Division Forest, Nature and Landscape, K.U. Leuven,

Celestijnenlaan 200E, 3001 Leuven, Belgium

J. De Baerdemaeker

Division of Mechatronics, Biostatistics and Sensors, K.U. Leuven,

Kasteelpark Arenberg 30, 3001 Leuven, Belgium 

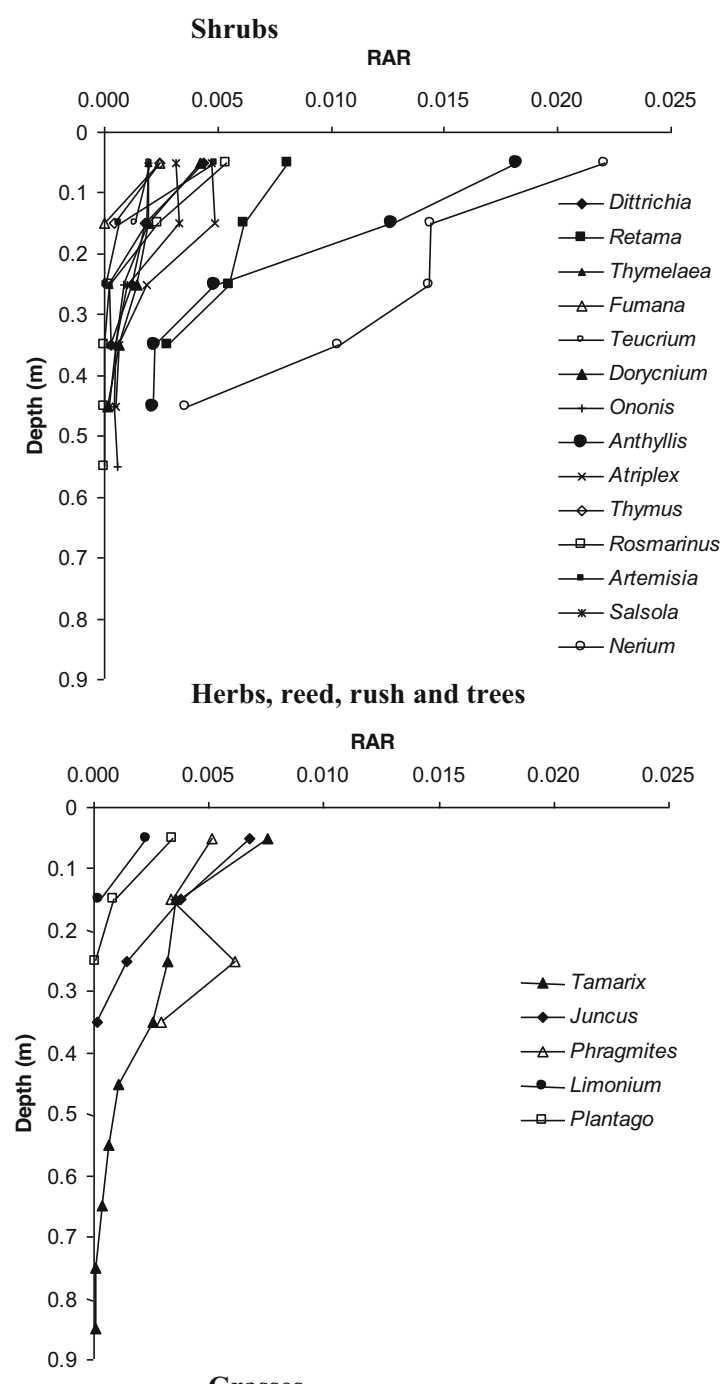

Grasses

RAR

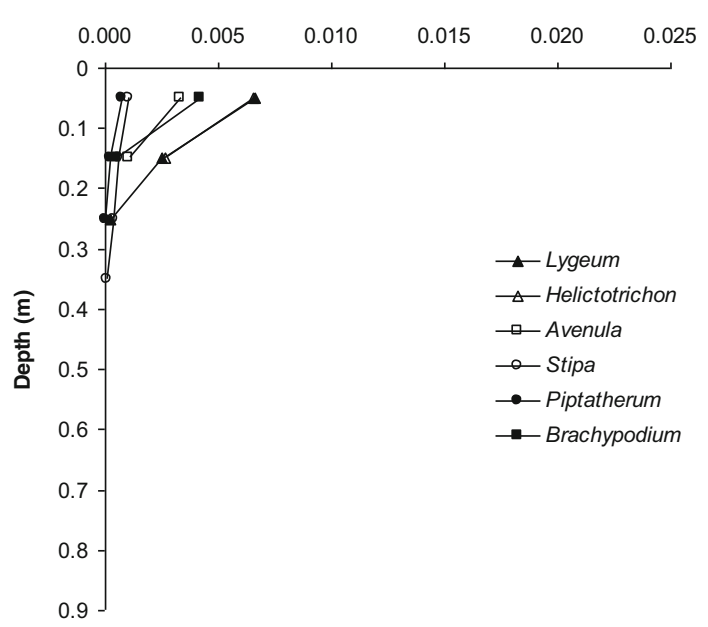

Fig. 4 Root area ratio $(R A R)$ distribution with depth for 25 typical Mediterranean plant species 